\title{
THE FIRST RECORDS OF THE IMOSAIC DISEASE OF SUGAR-CANE IN PUERTO RICO
}

By GEORGe N. WoLCOTT, Entomologist.

The purpose of the present note is to place on record the first observations on the occurrence of mosaic disease of sugar-cane in Puerto Rico, and to supplement the statement of Mr. J. A. Stevenson, Plant Pathologist of the Insular Experiment Station at the time of its discovery here, as to its early distribution. In his final, and presumably definitive, paper on "The Mottling or Yellow Stripe Disease of Sugar-Cane" (Jour. Dept. Agr. P. R., Vol. 3, No. 3, July, 1919), he writes:

"At the end of the first season's studies as noted in the 1915-16 report, it had attacked the eane in the region bordered by Aguadilla to the west and a line from Utuado to Arecibo along the valley of the Arecibo River on the east. Lack of time did not permit the working out of more exact boundaries, particularly along the south and west.",

During the grinding seasons of 1914-15 and 1915-16, the writer was devoting most of his time to making studies on the status of insects of sugar-cane in Puerto Rico, giving special attention to infestations of Diatraea saccharalis F., in mature stalks as observed when they were being harvested. Counts of infestations by the moth-borer in units of a hundred stalks were made, either in fields where the cane was being eut or at loading stations near-by, in all sections of the Island. On the status card, not only were spaces available for recording observations on what presumably would be all pertinent factors affecting the abundance or scarcity of the mothborer, and on the number noted of the other principal insects attacking stalks, but also "Phys. Dead-heart", "Root Disease" and "Other Injury". The only purpose of the entomologist in making observations on diseases was as they might affect the insects, and whenever diseased material was sufficiently abundant or interesting to justify bringing it back to Río Piedras, it was naturally turned over to the Plant Pathologist for determination.

On March 26, 1915, at Añasco, Tablon Pablo, concerning the field southwest of the long railroad bridge, (Status No. 148), containing mixed Rayada cane in first ratoon, the following was written: 
"The eane appeared to be dried up: small and shrunken between the joints. The lower part of the field was overflowed by the river and the cane was covered with silt. It appeared to be the worst cane.",

On the same day, cane at the loading station at Añasco, coming from Colonia Pacha in the hills, was noted to be "suffering from a stem disease like a leaf spot." Material was brought in to Mr. Stevenson, who examined it earefully at the time and stated that the lesions bore no traces of fungi or bactria, and that he had no idea of what might be the cause of the disease and would not even venture to make a tentative guess, without seeing young material, in an earlier stage of the disease. Travel was not so simple at that time, and as the entomologist had made a sufficient number of insect status examinations at that point for his purposes, the locality was not again revisited for obtaining the required material. Yet the written description of the cane, and his remembrance of the appearance of the lesions indicate that, without a doubt, it was severely cankered with mosaic disease, and definitely establishes a record for Añasco at least a year previous to any given by Stevenson, besides indicating by the condition of the cane that the disease must have been present here for at least two years previously, and possibly several more.

The disease was also present considerably to the south of Añasco, for when accompanied by Mr. R. H. Van Zwalumenburg on April 6, 1915, the status No. 154 at Colonia Carlo Bravo, between hills and the railroad by the road crossing to Mayagüez, bears the notation: "Leaf-spot stem disease."

The following year in April, 1916, status observations at Quebradillas, Camuy and Aguadilla record:

"The drying-out disease abundant-elongate lesions between the joints."

"A little of the drying-out disease." (three records)

"Drying-out disease abundant.",

"It was cane in a field near to this that suffered so severely from drying-up disease that two Centrals refused it. The buyer said he thought it was due to lack of air drainage. Rainfall had been ample." (Camuy.)

These rceords only confirm Stevenson's statements as to where he first found the disease. Other records made by the entomologist in this year, however, greatly extend the known range of the disease. - Status Nos. 166-7-8, all at Filial Amor, record:

"Drying-out disease abundant-bad." (at Colonia Rosario.)

"Drying-out disease abundant." (at Colonia Francisco Román.)

"More of drying-out disease." (at Colonia Emisa.) 
THE FIRST RECORDS OF THE MOSAIC DISEASE OF SUGAR-CANE IN P. R. 119

Filial Amor is the railroad junction northwest of San Germán, thus these records for 1916 indicate that even this early the disease must have existed far south of the area mapped by Stevenson, and that the original focus of infection may not have been in the hills back of Camuy, but possibly much farther south. 


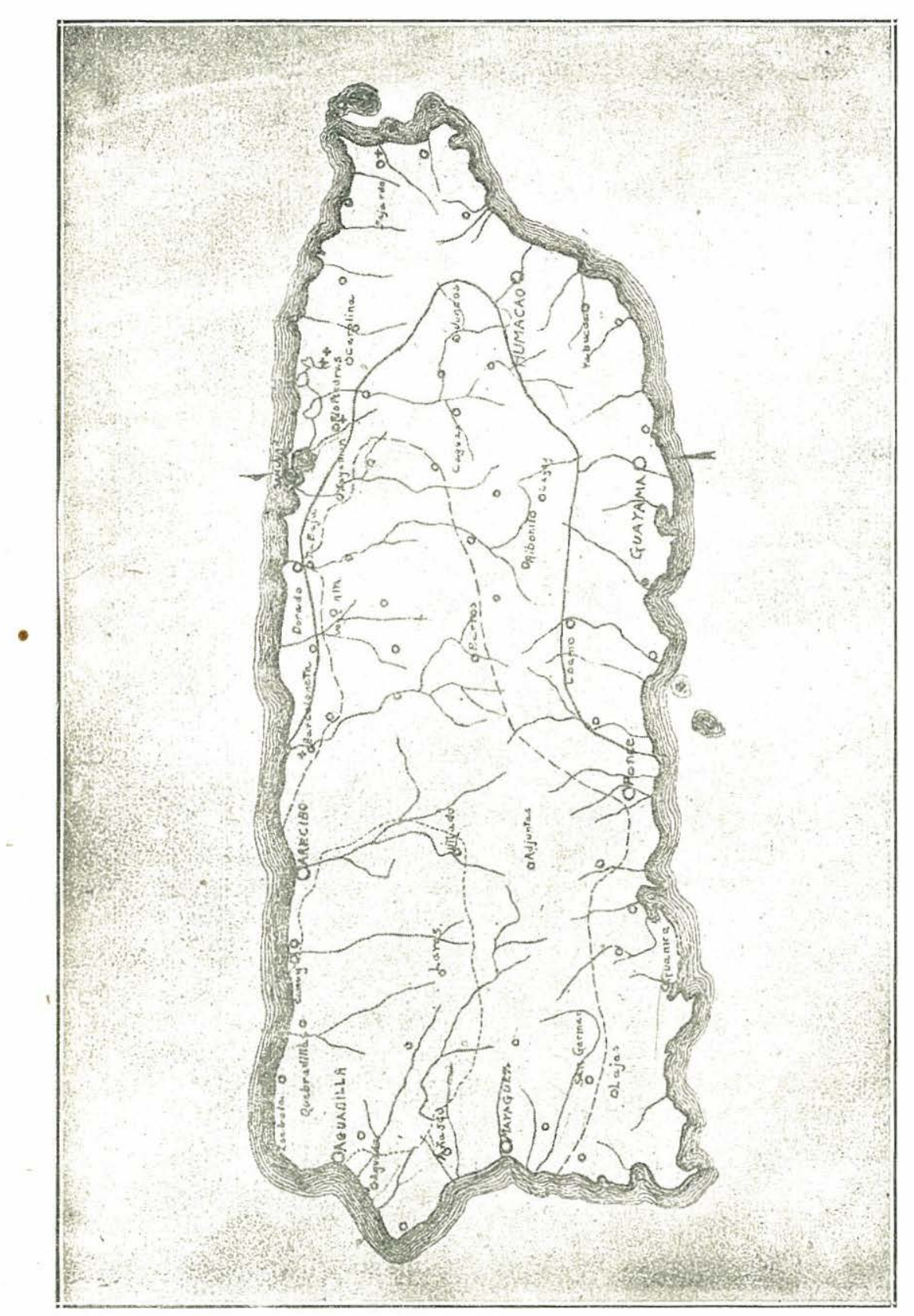

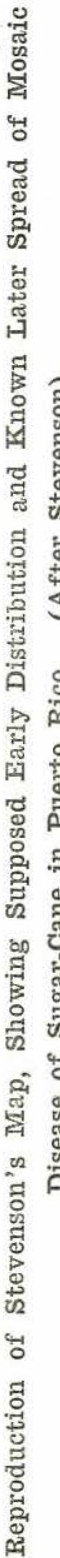

